\title{
看護婦勤務表作成支援システムの開発を意図したタスク 分析”
}

\section{嶋田葉子**, 池上敦子**, 大倉元宏**}

\begin{abstract}
Scheduling nurses to staff shifts is usually made by a head or chief nurse manually in Japan. The main difficulty of this scheduling is ensuring a certain level of service and skill, in every shift, is maintained while balancing the workload among the nurses involved. As a result it is usually impossible to develop a schedule which satisfies all the requirements, in spite of the time and resources spent in the effort. Although many computer support systems for nurse scheduling have been developed, they are usually considered difficult to use and ineffective. Our goal is to develop a useful computer support system for nurse scheduling. In this paper, first we surveyed existing support system and discussed why they were not used. Second, we performed task analysis for manual scheduling by a chief nurse in a hospital. In this analysis, we used "thinking aloud method" which is verbalizing what she is thinking as well as why she is doing what she is doing. As a result of this analysis, we found some functions for a useful system which enables a head or chief nurse to devote herself to scheduling without needing a prior knowledge of operating computers.
\end{abstract}

看護婦勤務表を作成するには，看護の質を守るだけでなく休日の均等化など考慮すべき条件が多 い.さらに手書きで作成するのが一般的であるため, 作成者である婦長や主任の多くはプライベート な時間まで費やして作成している，そのため，コンピュータによる作成支援システムが要望されてお り，今日までに様々な支援システムが開発されているが「使える」と評価されるものがないのが現状 である，そこで，本研究ではユーザーから支持される看護婦勤務表作成支援システムを開発すること を目的とした。 まず，既存の支援システムを見直して問題点を検討し，次に，現状作業を把握するた め, ある大学病院に勤務する主任看護婦を対象にして手書きによる勤務表作成にかかわる夕スク分析 を行った。 その結果，支援システムに必要ないくつかの機能が明らかになった. （キーワード：看護婦勤務表作成，交替制勤務，支援システム，夕スク分析，システム開発）

\section{1. はじめに}

病棟で働く看護婦の仕事は，1日24 時間を日勤・ 準夜勤・夜勤などの時間帯で分け，それらの勤務を $2 ， 3$ 日単位の短い周期でローテーションする交替制 によって行われている。その仕事内容は，同じ交替制 とはいえ工場などでみられる機械を対象としたルーチ ンワークとは異なり，患者ごとに，あるいは同じ患者

* 受付 2000 年 8 月 30 日 受理 2001 年 3 月 5 日

** 成蹊大学 工学部

Seikei University, Department of Industrial Engineering
でも病状や時間の経過に応じて変わるため予測が難し く，人間の生死にかかわる仕事の性質上，ぞの時間帯 においても急なトラブルに対応できる万全の体制が要 求されている1,2). 勤務を割り当てる婦長や主任は, 各時間帯の人数確保やメンバー構成を考慮して看護の 質が守られた勤務表を作成しなければならない。ささら に，この勤務表によって看護婦の生活パターンや収入 が決まってしまうことから，看護の質を守る他にも， 看護婦からの勤務希望, 休日の均等化, 夜勤明けの日 勤や連続 7 日間勤務などの禁止勤務パターンを排除し た無理のない勤務の並び，手当てが付くが体力的には きつい夜勤回数の平等性, 看護婦同士の相性, 研修や 
出張といった年中行事などの条件も考慮しなければな らず，婦長や主任は毎回頭を悩ませている( ${ }^{1 \sim 4}$. 多く の人が手書きで行っていることもあって, 勤務表作成 には相当な時間がかかり，プライベートな時間まで費 やすことがあるほど負担の大きい業務になってい $3^{4 \sim 6)}$. この負担を軽減するため, 企業や病院職員が コンピュータによる勤務表作成支援システム（以後, 支援システムとする）の開発を行っているが，現状で はユーザーからの評価があまり良くない苜 ${ }^{611)}$ そこで 本研究では，ユーザーから支持される支援システムを 開発することを目的とし，そのためには現状作業の把 握が重要であると考え, ある大学病院に勤務する主任 看護婦を対象にして手書きによる勤務表作成にかかわ るタスク分析を行った。その分析では，作成手順ごと に「何のために，何を考えてその作業を行っているの か? という作業者の思考内容について考察し, 支援 システムに必要な機能を明らかにすることを目指し た.

\section{2. 看護婦勤務表}

図 1 は多くの看護部署で使われている標準的な看護 婦勤務表を示したものである．表の左端にはその部署 に所属する看護婦名，上部にはひと月分の日付と曜日 が割り振られている．勤務表の右端には各看護婦の夜 勤回数や休日数をひと月分集計した数字，勤務表の下 部には各日にちの看護婦数を勤務別に集計した数字が 書かれている. それ以外のマス目は勤務の種類を示す 記号（例えば，日勤は「一」，夜勤は「〜」など）で 埋められており，先に述べた様々な条件を満たすよう に作成されている。

\section{3. 支援システムの現状と問題点}

支援システムに関する研究は，海外ではいくつかの

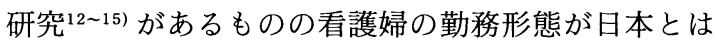
違い, ローテーション単位が 1,2 週間単位と長いこ とや，パートタイマーの採用や夜勤専従制を導入して いるため，それらのスケジューリングモデルは日本で 適用できない. 国内では，スケジューリングや人事管 理関係のシステムとの連動に重点を扔いたもの ${ }^{16 \sim 18)}$ があるが，スケジューリングのアルゴリズムにおいて 成功している例は一つ ${ }^{19)}$ しかなく，まだ実用には至 っていない. また, 画面に表示する情報量や入力操作 などューザーインターフェースに関する研究は皆無で あったので，具体的なユーザーインターフェースの情 報は, 日本医療情報学会論文集や看護情報システム研
究会講演集から 29 件, 市販されている支援システム のカタログ記載の情報や試用から 17 件, 計 46 件の支 援システムから集めた。

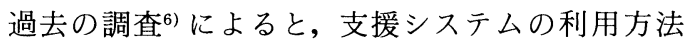
は，手書きで作成したスケジュールをコンピュータに 入力し, 看護婦数や勤務回数の自動集計による過不足 や禁止勤務パターンのエラーチェックだけを行うとい うものであり，スケジューリング機能自体はほとんど 利用されていない. その理由として，「考慮すべき条 件を満たすスケジュールができない」「手直しにかな り時間がかかる」「中途半端なスケジュールならない 方がいい」ということが挙げられている．勤務表を作 成するためには，勤務表作成対象期間，構成する看護 婦の資格や人数, 交替制の種類, 各勤務の必要人数, 禁止勤務パターン，年中行事などの項目に関する情報 が必要になるが, 項目内容も各項目の優先順位も部署 によって様々である.コンピュータにスケジューリン グをさせる場合には，これらのデータをあらかじめ入 力する作業が必要となり非常に手間がかかるだけでな く, 部署によっては設定項目が合わずにスケジューリ ング機能が利用できないため, あえてスケジューリン グ機能を外してエラーチェックと自動集計に重点を置 いて支援システムを開発したケースもある。

ユーザーインターフェースに関しては, 勤務表作成 の対象となる平均看護婦数は通常 20 名をこえる ${ }^{5,6,20)}$ のに対し， 1 画面に 20 人以上表示できる支援システ ムは数件程度しかない. 1 画面に全員が表示できない システムでは, 画面スクロールや画面の切り替え操作 によって残りの部分を表示しているが，「全員のひと 月分が一覧できず見にくい」「複数画面にわたつての 作業はやりずらい」という不満が出ている．また，勤 務表のように小さいマス目が並んだ表を用いる作業で は, 注目しているマス目の位置情報を得るためにカー ソルが重要な役割を果たすと思われるが, カーソルに ついての記述が全く見当たらない.このように，支援 システム開発においてューザーインターフェースが重 視されていないのが現状である.

これらの問題点や当面の実用性を考慮すると, 看護 婦数や勤務回数の自動集計機能とユーザーインターフ エースに重点を置き，スケジューリングは人間が行う タイプの支援システムの有効性が高いといえる. スケ ジューリング機能については, 的確なスケジューリン グ問題のモデル化やアルゴリズムの開発が必要であ り, その研究もわずかではあるが進められている ${ }^{19}$. しかし，スケジューリング部分だけは管理者の責任と して婦長や主任自身で行いたいという要求が多い5,6) ことや, 将来スケジューリング機能を利用する場合に 


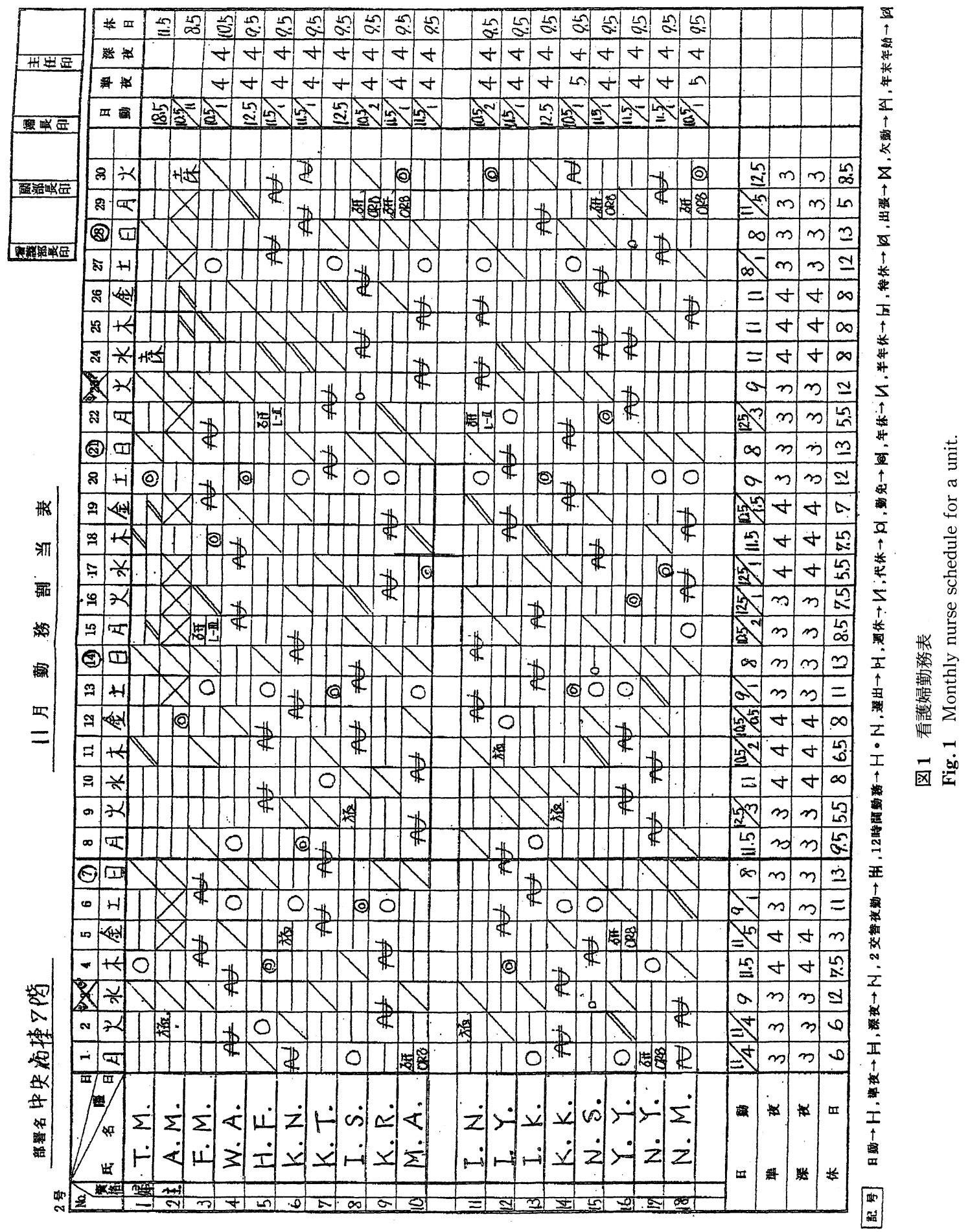


おいても，婦長や主任の考えを勤務表に反映させるた めの条件入力や修正作業が必要である10,11)ことから， 人間の思考を支援するためのユーザーインターフェー スは不可欠である。これらの理由から，本研究ではコ ンピュータの操作に煩わされることなく人間がスケジ ューリングに専念できるシステムに対象を絞り込んで 支援方法を導き出すことにする.

\section{4. 現状の勤務表作成におけるタスク分 析}

\section{4-1. 目 的}

ユーザーから支持される支援システムを開発するに は，まず第一に現状作業を把握することが重要であ る. 文献調查から，どの勤務表作成者も，夜勤や看護 婦からの勤務希望など優先順位の高い条件から満足す るように割り当てていく手順をとっており，使用する 道具もほほ共通していて個人間に大きな相違はないこ とがわかっている3,5,6,21). そこで，この作業をより深 く理解するため, 東京女子医大付属病院に勤務する主 任看護婦を対象にして現状の手書きによる勤務表作成 に関するタスク分析を行う。タスク分析では，作成手 順ごとに「何のために，何を考えてその作業を行って いるのか？」という作業者の思考内容に注目し，支援 システムに必要な機能を明らかにしていく。

\section{4-2. 方 法}

勤務表作成歷 10 年の主任看護婦に，実際の勤務表 を作成してもらい，その様子をビデオカメラで撮影し た。その間，作業の妨げにならない程度に思考内容を できるだけ発話するよう作業者に指示し，作業中に考 えていることを声に出す発話思考法22,23)を用いて言 語的なデー夕を収集することを意図した。そして，そ のデータを分析することにより，ビデオの画像だけで はわかりにくい「何のために，何を考えてその作業を 行っているのか?」という作業者の思考内容を明らか にした．作成した勤務表は 3 チームによる 2 交替の勤 務体制をとっている看護婦 26 人の 12 月分であった. 使用した道具は，12月の勤務表，先月の勤務表，白 紙の勤務表に各看護婦が希望する勤務を書き込んだ勤 務希望一覧表，3色ボールペン，鉛筆，修正液，消し ゴム, 長い定規 $(30 \mathrm{~cm}$ 位 $)$, 短い定規 $(10 \mathrm{~cm}$ 位 $)$ であった。他に，年末年始休暇を 12 月と翌年 1 月で 取得するため 2 つ月をまとめて作成することから， 12 月分を作成する時だけ必要なものとして翌年の 1 月の勤務表，年末年始の勤務可否一覧表も使用してい
た.

\section{4-3. 結 果}

\section{4-3-1． タスク分析からわかった作業内容}

ビデオによる画像や音声記録から，作業手順，発話 内容, 使用した道具の合理的意図を分析した。そし て，観察された作業を「何のために? 何を考えて行っ たのか？」について考察することからわかった作業者 の思考内容や，使用した道具，作業時間，割り当てた 勤務の種類を，勤務表作成の手順に沿って表 1 にまと めた．表 1 の大まかな内容は以下の通りである.

・手順 1 の「曜日を書き込む」作業は，平日は黒色， 土曜は青色, 日曜と祝日は赤色で曜日を書き込むこと で，曜日によって異なる各勤務の必要人数を間違えな いようにしたり，土日に休みを与える時の目印にした り，完成して看護婦たちに確認を取る時に見やすくす るために行っていた。

- 手順 2 の「週休と代休の数を数えて記入」作業は, 曜日欄を見ながら週休と代休の数を数えて闌外に記入 することで，作成中に週休や代休の数を確認したり， 代休とのバランスをとりながら週休を週に 1 回与える ことを忘れないようにするために行っていた。

- 手順 3 の「先月末の勤務を記入」作業は，作成中に 先月の勤務表を見ることなしに先月とつながりのある 勤務表を作成するため，各看護婦の先月末の勤務を欄 外に書き写していた。

- 手順 4 の「勤務免除の取得を記入」作業は, 病院の 定休日（毎月第三土曜）分の勤務である勤務免除とい う勤務を先月から今月に繰り越す看護婦の氏名欄の隣 に印をつけることによって，今月の勤務表で勤務免除 を割り当て忘れないようにするために行っていた。

- 手順 5 の「年休の残数を記入」作業は，作成中に各 看護婦の年休表を見ることなしに，残数が多い看護婦 から年休を割り当てて平等に年休を消化できるよう に，先月までの年休の残数を欄外に記入していた.

・手順 6 の「勤務希望を写しながら固定勤務を記入す る」作業では，勤務希望一覧表に書かれた看護婦の希 望する勤務と研修や出張のように変更できない公的な 勤務を固定勤務として記入していた．記入する時には 勤務の変更の可能性を判断して，変更の可能性があれ ば鉛筆を使い，変更の可能性がなければ消しゴムで消 せないようにボールペンを使って記入していた。

-手順 7 の「手順 6 の見直しをしつつ，12 月に限り 夜勤と 30 日と 31 日の仮勤務を書き写す」作業は, 勤 務希望を間違えて写すと勤務割り当て後の修正が困難 になるので見直しを行っていた。そして，1月までの 間に看護婦全員が年末年始休暇を取得することから， 
表 1 手書きによる看護婦勤務表作成作業のタスク分析結果

Tab. 1 Results of a task analysis on nurse scheduling by manually.

\begin{tabular}{|c|c|c|c|c|c|c|c|c|c|c|c|c|c|}
\hline \multirow{2}{*}{\multicolumn{2}{|c|}{ 作成手順 }} & \multirow{2}{*}{ 観察内容 } & \multirow{2}{*}{$\begin{array}{l}\text { 思考内容（何のために? 何を考えてその作業をした } \\
\text { のか） }\end{array}$} & \multirow{2}{*}{ 使用道具 } & \multirow{2}{*}{ 作業時間 } & \multicolumn{8}{|c|}{ 割り当てた勤務※ } \\
\hline & & & & & & & 勤夜勤 & & & 勤兔 & & $\mathrm{HP}$ & 運出 \\
\hline 1 & $\begin{array}{l}\text { 曜日を書き込 } \\
\text { む }\end{array}$ & $\begin{array}{l}\text { 平日は黒, 土曜は青, } \\
\text { 日・祝は赤で書く. }\end{array}$ & $\begin{array}{l}\text { 曜日によって勤務の必要人数が異なるのでわかりや } \\
\text { すいように. 完成して看護婦たちに確認を取る時に } \\
\text { 見やすいから. 土日に休みを与える時の目印にな } \\
\text { る. }\end{array}$ & \begin{tabular}{|l|}
12 月勤務表, \\
3 色ボールペ \\
ン
\end{tabular} & 1 分 28 秒 & & & & & & & & \\
\hline 2 & $\begin{array}{l}\text { 週休と代休の } \\
\text { 数を数えて記 } \\
\text { 入 }\end{array}$ & $\begin{array}{l}\text { 曜日欄を見ながら数え } \\
\text { る. }\end{array}$ & $\begin{array}{l}\text { 勤務表作成時に週休や代休を与えることを意識する } \\
\text { ため. 週休はほほ週に1日になるようにしながら代 } \\
\text { 休とのバランスを見て作成するので数を忘れないよ } \\
\text { うに記入. }\end{array}$ & $\begin{array}{l}12 \text { 月勤務表, } \\
\text { 鉛筆 }\end{array}$ & 5 秒 & & & & & & & & \\
\hline 3 & $\begin{array}{l}\text { 先月末の勤務 } \\
\text { を記入 }\end{array}$ & $\begin{array}{l}\text { 名前の横の欄に先月の勤 } \\
\text { 務表を見ながら, 各看謢 } \\
\text { 婦の勤を務を書き写してい } \\
\text { く.勤務の種類は日勤の } \\
\text { 回数, (1 回/2回連 続) } \\
\text { 夜勤入り/明け, 週休, } \\
\text { 代休, 年休など. }\end{array}$ & 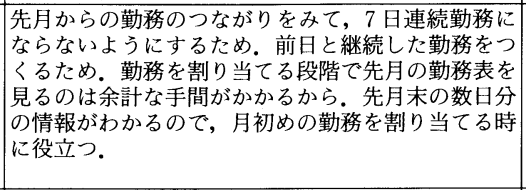 & \begin{tabular}{|l|}
12 月勤務表, \\
先月筑務 \\
表, 鉛筆, 消 \\
しゴム, 短い \\
定規
\end{tabular} & 1 分 14 秒 & 0 & 0 & 0 & 0 & 0 & 0 & 0 & O \\
\hline 4 & \begin{tabular}{|l|} 
勤務免除の取 \\
得を記入
\end{tabular} & $\begin{array}{l}\text { 名前の横の欄外に先月の } \\
\text { 勤務表を見ながら,勤務 } \\
\text { 兔除を今に繰り越す看 } \\
\text { 護婦に記号 (@)を畫いて } \\
\text { いく. }\end{array}$ & $\begin{array}{l}\text { 病院のきまりで, } 3 \text { 時間勤務を月 } 1 \text { 回与える. 先月 } \\
\text { その勤務を割り当てなかったら翌月に } 1 \text { 日休みをあ } \\
\text { げなければならない. その勤務除を忘れないよう } \\
\text { に.割り当てる時に } 3 \text { 時間か } 1 \text { 日かどっちか書いて } \\
\text { おく. }\end{array}$ & \begin{tabular}{|l|}
12 月勤務表, \\
先月勤務 \\
表, 鉛筆, 消 \\
しゴム, 短い \\
定規
\end{tabular} & 38 秒 & & & & & 0 & & & \\
\hline 5 & $\begin{array}{l}\text { 年休の残数を } \\
\text { 記入 }\end{array}$ & $\begin{array}{l}\text { 先月の勤務表の欄外に集 } \\
\text { 計しておいた年の残数 } \\
\text { を同じ位置の欄外に書き } \\
\text { 写す. }\end{array}$ & $\begin{array}{l}\text { 年休を平等に消化できるように，また使い過ぎない } \\
\text { ように. 勤務を割り当てる際に各看護婦の年休表を } \\
\text { 見なくても済むように. } \\
\end{array}$ & $\begin{array}{l}12 \text { 月勤務表, } \\
\text { 先月 } の \text { 勤務 } \\
\text { 表, 鉛筆, 消 } \\
\text { しゴム }\end{array}$ & 1 分 8 秒 & & & & & & & & \\
\hline 6 & \begin{tabular}{|l} 
勤務希望を写 \\
しながら固定 \\
勤務を記入す \\
る
\end{tabular} & 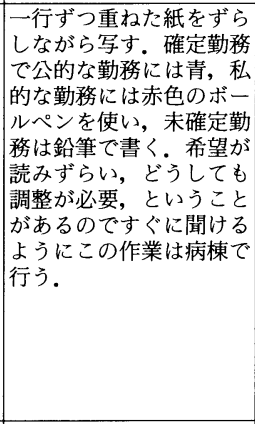 & 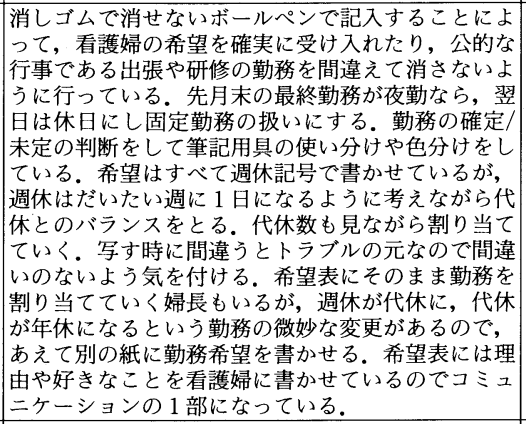 & \begin{tabular}{|l|}
12 月勤務表, \\
勤表希望一覧 \\
表, 3 色ボ \\
ル 鉛 \\
筆, 消し 声 \\
厶, 短い定規 \\
\\
\end{tabular} & 8 分 50 秒 & O & 0 & 0 & 0 & & & & \\
\hline 7 & 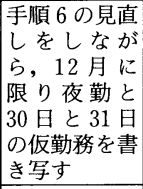 & $\begin{array}{l}12 \text { 月は } 29 \text { 日をよ日とし } \\
\text { て考える.12月は勤務 } \\
\text { が夕イトなので, 方か } \\
\text { じめ割り当てた夜勤を書 } \\
\text { き写す. } \\
\end{array}$ & 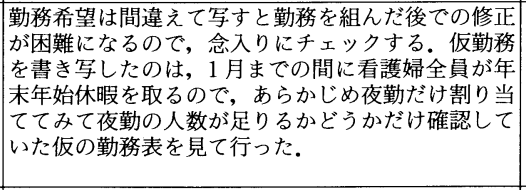 & \begin{tabular}{|l|}
12 月勤務表, \\
勤務希望一覽 \\
表, 鉛筆, 消 \\
しゴム, 短い \\
定規
\end{tabular} & 4 分 27 秒 & 0 & 10 & 0 & & & & & \\
\hline 8 & $\begin{array}{l}\text { 手術日の夜勤 } \\
\text { 人数欄に印を } \\
\text { 記入 }\end{array}$ & \begin{tabular}{|l|} 
手術日（水・木・金曜） \\
の夜勤の人数欄に印をつ \\
けておくく.
\end{tabular} & $\begin{array}{l}\text { 水・木・金曜は夜勤が } 1 \text { 名多く必要なので忘れない } \\
\text { ように. 夜勤の人数は確実に揃えないといけない. }\end{array}$ & \begin{tabular}{|l|}
12 月勤務表, \\
鉛筆, 短い定 \\
規
\end{tabular} & 37 秒 & & & & & & & & \\
\hline 9 & $\begin{array}{l}\text { 夜勤を割り当 } \\
\text { てる }\end{array}$ & 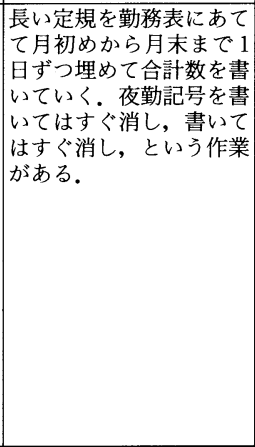 & 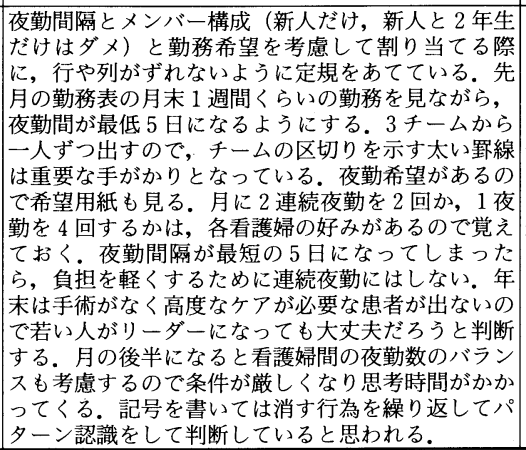 & 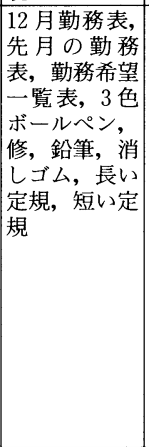 & 29 分 27 秒 & & O & & & & & & \\
\hline
\end{tabular}




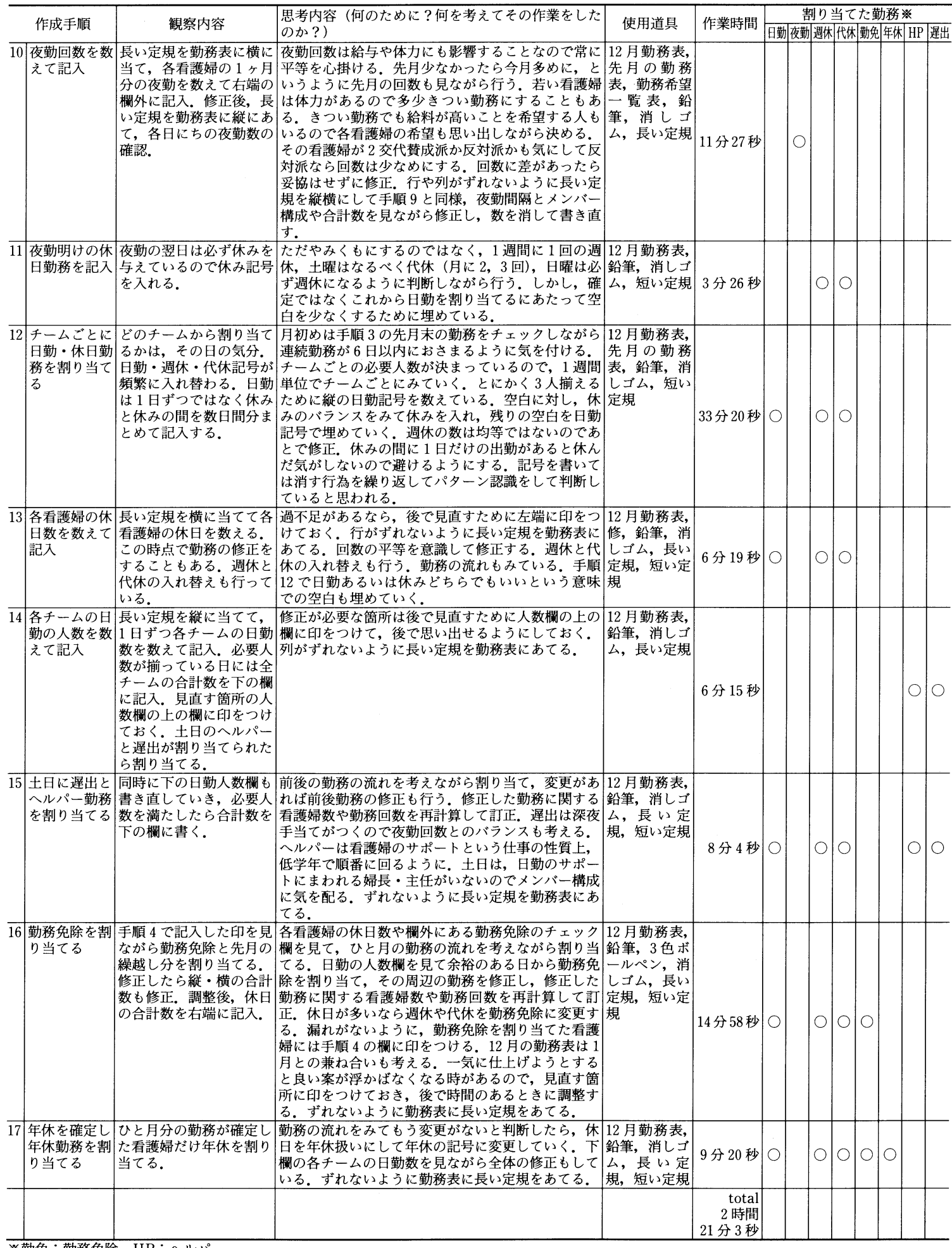


あらかじめ夜勤だけ割り当てて夜勤の人数が足りるか 確認していた仮の勤務表を見て写していた。ただ，今 回作成する 12 月の勤務表は事務処理上 29 日が締め日 なので，1月分に含まれる 30 日と 31 日の勤務だけを 写した.

- 手順 8 の「手術日の夜勤人数欄に記入」作業は，夜 勤の必要人数が多い手術日（水・木・金曜）の夜勤人 数欄に印をつけておくことによって, 夜勤の人数を確 実に揃えることを忘れないようにするために行ってい た.

•手順 9 の「夜勤を割り当てる」作業は, 視線がずれ ないように長い定規を勤務表にあてて行っていた。夜 勤間隔や看護の質が守られるようなメンバー構成かど うかを考慮しながら, 月初めから月末まで 1 日ずつ看 護婦を割り当てて合計数を書いていた。この時, 夜勤 記号を書いてはすぐ消すという行為を繰り返すことに よって, 勤務の並びをパターン認識しているようだっ た.

- 手順 10 の「夜勤回数を数えて記入」作業は, 視線 がずれないように長い定規を勤務表にあてて行ってい た. 各看護婦の 1 ヶ月分の夜勤回数を数えて右端の闌 外に記入し, 夜勤回数が全員均等になっているか確認 していた．夜勤回数は看護婦の給料や体力に大きく影 響するので, 回数に偏りがなくなるまで手順 9 と手順 10 を繰り返し，納得できるまで修正していた。

- 手順 11 の「夜勤明けの休日勤務を記入」作業は, 夜勤の翌日に必ず与える休みの記号を記入していた。 この作業は，これから日勤を割り当てる際に空白のマ ス目を少なくする意味があり，ただやみくもに記入す るのではなく, 土曜はなるべく代休, 日曜は必ず週 休, 週休は 1 週間に 1 回になるように判断しながら行 っていた。

・手順 12 の「チームごとに日勤・休日勤務を割り当 てる」作業は，連続勤務が 6 日以内におさまるように 休みを入れ，残りの空白のマス目を日勤で埋めてい た。日勤は 1 マスずつではなく休みと休みの間の数マ ス分をまとめて記入していた。その間，1つのマス目 に日勤・週休・代休記号を書いてはすぐ消すという行 為を繰り返して，思いついた勤務記号を記入すること によって勤務の並びをパターン認識しているようだっ た.

- 手順 13 の「各看護婦の休日数を数えて記入」作業 は，視線がずれないよう長い定規を勤務表にあてて行 っていた. 各看護婦の 1 ケ月分の休日数を数えて右端 の欄外に記入し，休日数が全員均等になっているか調 べていた．数に過不足がある場合は勤務の修正をする こともあるが，ここでは無理に修正せず後で見直すた
めに看護婦名の横に印をつけていた。

• 手順 14 の「各チームの日勤の人数を数えて記入」 作業は，視線がずれないように長い定規を勤務表にあ てて行っていた。 1 日ずつ各チームの日勤の人数を数 えて記入し，必要人数が揃っている日には全チームの 合計数をその下の欄に記入していた，修正が必要な箇 所は後で見直すために人数欄の上に印をつけていた。

・手順 15 の「土日に遅出とヘルパー勤務を割り当て る」作業は，視線がずれないように長い定規をあてて メンバー構成や勤務の並びを見ながら，土日だけ必要 な遅出勤務と他の看護婦のサポート役にまわるへルパ 一勤務を割り当てていた．他の勤務を修正したらその 勤務に関する看護婦数や勤務回数を数え直して修正し ていた.

・手順 16 の「勤務免除を割り当てる」作業は, 視線 がずれないように長い定規を勤務表にあてて行ってい た. 各看護婦の休日数や手順 4 で記入した印を見て勤 務の並びを見ながら勤務免除を割り当てていた。他の 勤務を修正したらその勤務に関する看護婦数や勤務回 数を数え直して修正していた.

-手順 17 の「年休を確定し年休勤務を割り当てる」 作業は，視線がずれないように長い定規を勤務表にあ てて勤務の並びを見て，もう変更がないと判断した看 護婦だけに年休勤務を割り当てていた。ここまでを仮 の勤務表とし，後日，何日間かかけて勤務の平等性や 偏りを見直して清書することにしていた。

以上が観察できた仮の勤務表完成までの大まかな内 容であるが, 特に注目すべき点が 4 つ挙げられた。

(1) 手順 9 の夜勤を割り当てる作業では, 夜勤間隔や メンバー構成を見渡す際に，長い定規を勤務表にあて て視線のずれをふせぐ手がかりにしていることがわか った。この長い定規を勤務表にあてる行為は，夜勤以 外の勤務を割り当てる時や勤務回数を数える時にも頻 繁に観察された。

(2) 手順 13 や 14 では欄外に印をつけることがあった が，これは後で見直す時に，修正が必要な箇所がわか るようにして記憶の負担を軽くするために行ってい た.

（3）夜勤については，手順 8 で必要人数の多い日に印 を記入していたり, 手順 9 と手順 10 を繰り返して他 の勤務より優先的に何度も修正していたことから，必 ず人数を揃えなければならない最も重要な勤務である ことがわかった。

（4）勤務記号の記入においては，作業内容によって使 う勤務記号が限られていたり，手順 12 に見られるよ うに，1つのマス目に複数の勤務記号を記入しては消 すという行為を繰り返していたり，数日分まとめて勤 
務記号を記入するなど，様々な記入方法があることが わかった。

この他にも，たびたび先月の勤務表を取り出して情 報を読み取っていること（手順 $3 ， 4 ， 5 ， 9 ， 10 ， 12$ ) や，メンバー構成を考えたりチーム別で勤務割り当て や集計を行う際にチームの区切りを示す太い買線を手 がかりにしていること（手順 9，12，14～17）がわか った.

\section{4-3-2. 作業内容の分類}

次に，勤務表作成においてコンピュータで支援でき る作業は何であるかを検討するため, これらの作業内 容をいくつかの項目に分類した。分類は，作業者が機 械的に行っている単純な作業か，または多くの判断要 素があって作業者が思考しながら行っている複雑な作 業かどうかを基準にした。その結果，単純な作業とし て, 曜日や希望勤務を写す「表示」, 休日の残数や先 月末の勤務を書く「記入」, 勤務回数や看護婦数を数 える「計算」があった。一方，思考を含む複雑な作業 として,メンバー構成や無理のない勤務の並びを考慮 しながら勤務を割り当てていく「勤務割り当て」と, 勤務や看護婦を入れ替えて修正する時に行っている， 勤務割り当てをしながら勤務回数や看護婦数を再計算 して数を書き直す「勤務割り当て十計算十記入」があ った。これらの項目ごとに作業時間を集計したものを 表 2 に示す。これによると,コンピュータで比較的簡 単に支援できる「表示」「計算」「記入」といった単純 な作業にかかる時間が多いことがわかった。

\section{4-4. 考 察}

タスク分析の結果から，支援システムに必要なユー ザーインターフェース機能として，(1) 視線のずれを ふせぐ手がかり，(2) 見直し用の印をつける欄，(3) 夜 勤人数に過不足がある場合の警告, (4) 効率的な勤務

表 2 看護婦勤務表作成作業の分類結果

Tab. 2 Classification of tasks in the process of completing a table for nurse scheduling.

\begin{tabular}{l|l|c}
\hline 作業分類項目 & $\begin{array}{l}\text { 作業内容 (表 } 2 \text { 作 } \\
\text { 成手順に対応) }\end{array}$ & 合計作業時間 \\
\hline 表示 & 1,6 & 10 分 18 秒 \\
\hline 記入 & $2,3,4,5,8$ & 3 分 42 秒 \\
\hline 計算 & $10,13,14$ & 24 分 01 秒 \\
\hline 勤務割り当て & $7,11,12,17$ & 50 分 33 秒 \\
\hline $\begin{array}{l}\text { 勤務割り当て+計 } \\
\text { 算十記入 }\end{array}$ & $9,15,16$ & 52 分 29 秒 \\
\hline
\end{tabular}

(総作業時間 2 時間 21 分 03 秒)
記号の入力方法が挙げられる. 表 2 からは，スケジュ ーリングは人間が行うとしても, コンピュータで「表 示」「計算」「記入」の支援ができれば作業時間を大幅 に短縮できる可能性があるとわかったので，この分類 を参考にして, 勤務表作成作業をコンピュータで支援 する部分と人間が受け持つ部分に切り分けて開発する ことが重要だと思われる。

今回のタスク分析では，すでに文献から明らかにな っている作成手順や使用した道具を知るのではなく, 「何のために? 何を考えて行ったのか？」という作業 者の思考内容を知ることに注目している，例えば，夜 勤を割り当てるときに長い定規を使用したが, 長い定 規自体が問題なのではなく，「何のために」長い定規 を使用したのか，つまり「夜勤間隔やメンバー構成を 正確に見渡すため」に使用したのであり，支援システ ムには「視線のずれをふせぐ手がかりが必要」である ことを導き出すのが目的だった。これらの目的が達成 できたのは，一例に絞りながらも徹底的に観察と分析 を行った結果であると考える。

\section{5. 総 括}

既存の支援システムの問題点を検討した結果，スケ ジューリング機能の開発は必要であるが，中途半端な スケジューリング機能よりは，自動集計機能付きでュ ーザーインターフェースに十分配慮した支援システム の方が当面の実用性が高いと考えた。そこで本研究で は，「コンピュータの操作に煩わされることなく人間 がスケジューリングに専念できるシステム」を目指し た。この支援システムはスケジューリング機能を否定 するのではなく, 将来有効なスケジューリングのアル ゴリズムを組み込むときに，それを有効に機能させる ためにも重要な役割を果たすと考える。

タスク分析からは，支援システムに必要と思われる 4 つの具体的なユーザーインターフェース機能や，勤 務表作成作業をコンピュータで支援する部分と人間が 受け持つ部分に切り分けるために役立つ分類を明らか にすることができた。このタスク分析は作業者の思考 内容に注目しているため, 今回のユーザーインターフ エースに対してだけでなく，スケジューリングの研究 はもちろん，勤務表作成作業全体や看護婦の給与計算 など周辺作業の研究にも応用することができ，表 1 は それらに有効な情報を与えると考える。

現在の勤務表作成者の苦労を考えると，スケジュー リング機能を備えた支援システムを早い時期に実用化 しなければならない. しかし，勤務表は病院関係者に とって単なる仕事の割り当て以上の重要な意味をもつ 
ので，そこに作成者の考えを完璧に反映できるように しなければ支援システムとして役に立たないことも事 実である．安易にコンピュータを利用したがために， それに人間が合わせなければならなくなるのではな く，あくまでも人間を中心に考え，それに合ったコン ピュータでの支援方法を検討していくことが重要であ ると考える.

今後は，このことを念頭において具体的に支援シス テムの開発を行っていく.

謝辞 本研究を行うにあたりご協力賜りました東京 女子医大付属病院の安藤主任, 成蹊大学の窪田悟助教 授に感謝いたします。

\section{参考文献}

1）山崎慶子, 嶋森好子, 浅川明子, 未安民生：シフ トワーク・マニュアル，日本看護協会出版会，東 京, 1996.

2）波多野梗子：看護の管理, 湯槙ます,系統看護学 講座 10 看護学総論, 371 406, 東京, 医学書院, 1986.

3）宮子あずさ：まるごと 1 冊勤務表!, Nursing Today, 12, 1997.

4）粟屋典子: 勤務計画表, 矢野正子, 看護管理一シ ステムアプローチー第 2 版, 223〜230, HBJ 出版 局, 東京, 1995.

5）池上敦子, 相澤 学, 大倉元宏, 若狭紅子, 松平信 子, 越河六郎：ナース・スケジューリング・シス テム構築のための基礎的調查研究，労働科学， 71 (10) , 413 423, 1995.

6）池上敦子, 越河六郎：看護婦勤務表作成におけ るアンケート調査, 私立医科大学病院看護部長会 （総婦長会）調查報告書資料, 12, 1997.

7）竹本敬子：コンピュータを導入した看護婦勤務 表作成の現状と課題，看護管理，3(1)，38～42, 1993.

8）宇都由美子：より実用性，柔軟性の高いシステ 么の構築, 看護管理, 3(2), 120～125, 1993.

9）佐々木悠子：コンピュータによる看護婦勤務割 当表作成, 看護管理, 3(3), 171〜176, 1993.

10）櫻井律子：看護婦勤務割当表作成ワープロと統 合勤務管理システム，看護管理，3(4)，260～265,
1993.

11）加藤千津子：勤務管理支援システムの導入から 改善の経緯と現況，看護管理，3(5)，319〜 325, 1993.

12) Bell, P. C., Hay, G., \& Liang, Y.: A Visual Interactive Decision Support System For Workforce (Nurse) Scheduling, INFOR, 24 (2), 134 145, 1986.

13) Ozkarahan, I., \& Bailey, J. E.: Goal Programming Model Subsystem of a Flexible Nurse Scheduling Support System, IIE Transactions, 20 (3) , 306 316, 1988.

14) dowsland, K. A. : Nurse Scheduling with Tabu Search and Strategic Oscillation, European Journal of Operational Research, 106, 393 $\sim 407,1998$.

15) Jaumard, B., Semet, F., \& Vovor, T.: A Generalized Linear Programming Model for Nurse Scheduling, European Journal of Operational Research, 107, 1 18, 1998.

16）岡本康幸：遺伝的アルゴリズムを応用した勤務 配置計画支援プログラム, 医療情報学雑誌, 14 (1), 31 34, 1994.

17）長野弘志, 宮崎茂次：勤務に対する嗜好の個人 差を考慮した看護婦スケジューリング，日本経営 工学会論文誌, $47(3), 143 \sim 149,1996$.

18）佐藤 弥, 盛 直久: 看護職員勤務表作成シス テムと超過勤務命令簿の連動, 医療情報学雑誌, 17 (2), 125〜131, 1997.

19）池上敦子, 丹羽 明: ナース・スケジューリン グに有効なアプローチアプローチー2 交替制アル ゴリズムにおける実現一,オペレーションズ・リ サーチ, 41(4), 572〜 588, 1998.

20）厚生省大臣官房統計情報部編：平成 8 年度医療 施設調査・病院報告, 厚生省, 1998 .

21）池上敦子, 丹羽 明, 大倉元宏：我が国における ナース・スケジューリング問題, オペレーション ズ・リサーチ, 41(8), 436〜442, 1996.

22）海保博之, 原田悦子：プロトコル分析入門一発 話データから何を読むか一, 新曜社, 東京, 1993.

23）原田悦子：プロトコル分析, 海保博之, 加藤 隆, 認知研究の技法, 79〜84, 福村出版, 東京, 1999. 